\title{
IDENTIFIKASI EKTOPARASIT PADA INSANG IKAN MAS KOKI (Carassius auratus)
}

\author{
Reni Anggraini ${ }^{1}$, Endang Sulistyarini Gultom² \\ ${ }^{1}$ Mahasiswa Biologi FMIPA Universitas Negeri Medan \\ ${ }^{2}$ Staf Pengajar Program Studi Biologi FMIPA Universitas Negeri Medan \\ renianggrayni07@gmail.com
}

\begin{abstract}
ABSTRAK
Penelitian ini bertujuan untuk mengetahui jenis-jenis parasit yang menginfeksi pada insang ikan mas koki (Carassius auratus). Penelitian ini dilaksanakan pada bulan Mei 2017, di Laboratorium Biologi Universitas Negeri Medan. Pemeriksaaan ektoparasit dilakukan dengan menggunakan metode pengapungan, dimana sampel insang direndam didalam larutan garam fisiologis yang kemudian dibiarkan selama 5 menit. Dari hasil penelitian ditemukan 2 jenis parasit yang menginfeksi insang ikan mas koki (Carassius auratus), yaitu Unitubulotestis sardae dan Dactylogyrus sp.
\end{abstract}

Kata Kunci : Parasit, Insang, Carassius auratus, ektoparasit.

\section{Identification of Ectoparasites on Gill Fish Mas Koki (Carassius auratus)}

\section{ABSTRACK}

This study aims to determine the types of parasites that infect the gills of goldfish (Carassius auratus). This research was conducted in May 2017, at the Biology Laboratory of Medan State University. Ectoparasite examination was performed using floatation method, where gill samples were immersed in physiological salt larvae which were then left for 5 minutes. From the results of the study found two types of parasites that infect the gills of goldfish (Carassius auratus), namely Unitubulotestis sardae and Dactylogyrus sp.

Keywords: Parasites, Gills, Carassius auratus, ectoparasites.

\section{Pendahuluan}

Usaha perikanan di Indonesia saat ini berkembang dengan begitu pesat, baik dari sektor ikan hias maupun ikan konsumsi (Tuti dan Yani, 2010). Dengan luasnya perairan di Indonesia khususnya perairan air tawar yang berpotensi untuk melakukan usaha ikan hias. Saat ini, usaha ikan hias air tawar sangat diminati oleh masyarakat karena menguntungkan. Ikan hias yang saat ini populer dan diminati masyarakt adalah ikan arwana dan ikan mas koki. Tetapi ikan arwana mempunyai harga yang cukup tinggi dibandingkan dengan ikan mas koki (Carassius auratus), sehingga masyarakat menengah kebawah ebih tertarik dengan ikan mas koki (Carassius auratus). Selain dari harga yang cukup terjangkau, ikan mas koki (Crassisu auratus) juga memiliki keunikan lain yaitu dari bentuknya yang unik serta memiliki warna yang cerah (Effendi, 2013). Pemeliharaan ikan hias mas koki tidak luput dari penyakit, terutama penyakit yang disebabkan oleh serangan parasit.

Parasit merupakan organisme yang dapat menyebabkan kematian pada ikan. Perkembangbiakan parasit ini dapat terjadi apabila, pada kolam jika kolam tersebut kurang perawatannya, pakan yang berlebihan, perubahan lingkungan yang dapat menurunkan resistensi ikan tersebut. Parasit hidup secara menumpang pada organisme lain yang menyebabkan kerugian pada organisme yang ditumpangi. Tempat parasit hidup dinamakan inang yang berperan sebagai tempat nutrien, tempat hidup dan tinggal. Parasit pada ikan adalah parasit yang hidup di tubuh ikan dan menjadikan ikan sebagai inang (Usy dan Fatmawati, 2016).

Parasit yang menyerang ikan, terutama pada insang ikan dikelompokkan ke dalam ektoparasit. Ektoparasit adalah parasit yang hidup permukaan luar tubuh inang atau di dalam liang-liang kulit ikan. Dampak negatif yang ditimbulkan dari adanya parasit pada tubuh ikan akibat serangan ektoparasit terlihat jelas pada tubuh luar ikan (Purbomartono, 2010). Menurut Liviawaty dan Afrianto (1990), diantara penyakit atau parasit yang sering menyerang ikan mas koki yang dipelihara di kolam-kolam atau akuarium adalah dari golongan ektoparasit 
seperti: Argulus, Lernea, Ichtyophthirius, Dactylogyrus, dan Gyrodactylus.

Parasit yang menyerang ikan budidaya akan mempengaruhi kelangsungan hidup seperti terhambatnya pertumbuhan ikan. Pengaruh yang muncul diawali dengan terganggunya sistem metabolisme tubuh hospes sampai merusak organ (seperti insang, lambung dan usus), sehingga dapat mempengaruhi pertumbuhan ikan, bahkan dapat menyebabkan kematian. Daur hidup parasit yang menginfeksi ikan budidaya dapat diketahui melalui hubungan antara hospes yaitu biakan budidaya, parasit serta lingkungan hospes tersebut hidup, sehingga para pembudidaya ternak dapat mengantisipasi keadaan yang timbul akibat parasit tersebut (Nofyan dkk, 2015).

\section{Bahan dan Metode Alat dan Bahan}

Alat-alat yang digunakan dalam pelaksanaan penelitian ini adalah bak paraffin, gunting bedah, pinset bedah, cawan petri, mikroskop, pipet tetes, timbangan analitik, object glass. Sedangkan bahan yang digunakan adalah ikan mas koki (Carassius auratus), larutan garam fisiologis, aquades.

\section{Teknik Pengambilan dan Penanganan Sampel} Penelitian ini dilakukan dengan menggunakan 3 ekor sampel ikan yag dibeli di tempat penjualan ikan hias tepatnya di Jalan Bintang, kota Medan Sumatera Utara. Selanjutnya sampel ikan dibawa ke Laboratorium Biologi Fakultas Matematika dan Ilmu Pengetahuan Alam Universitas Negeri Medan dengan menggunakan plastik yang di dalamnya terdapat air dan oksigen. Setelah itu dilakukan pemotongan dan pembedahan pada bagian tubuh ikan untuk pemeriksaan parasit.

\section{Pemeriksaan Parasit Pada Insang}

Sampel ikan yang berada di dalam kantong plastik dimasukkan ke dalam ember. Setelah itu sampel diambil satu persatu dan dimatikan dengan cara menusukkan jarum tepat pada bagian medulla oblongata. Kemudian dilakukan pembedahan dan pemotongan pada bagian operkulum sehingga lembaran insang jelas kelihatan. Lembaran insang diambil, keudian di masukkan ke dalam cawan petri yang telah berisi larutan garam fisiologis dan direndam selama 5 menit. Kemudian setelah 5 menit air rendaman insang tersebut diteteskan di object glass kemudian diamati dibawah mikroskop. Hasil pengamatan dirujuk pada buku Kabata dan jurnal penelitian yang membahas masalah yang sama.

\section{Hasil Dan Pembahasan}

Pada penelitian ini menggunakan tiga ekor ikan mas koki (Carassius auratus). Setelah dilakukan pengamatan dan identifikasi menggunakan literatur buku karangan Kabata dengan mengidentifikasi berdasarkan morfologi, yaitu dari bentuk tubuh, warna tubuh, organ perlekatan pada inang, serta ukuran tubuh. Dari identifikasi berdasarkan kriteria morfologi yang telah ditentukan dapat diketahui bahwa pada ikan mas koki yang diamati terdapat ektoparasit dari kelas Monogenea dan Cestoidea.

Pada kelas Monogenea ciri-ciri parasit yang ditemukan berdasarkan hasil pengamatan pada morfologi termasuk dalam Genus Dactylogyrus. Cacing ini termasuk dalam Filum Platyhelminthes karena memiliki bentuk tubuh pipih dan memiliki organ pelekatan pada inang (Kabata,1985), Kelas Monogenea karena berbentuk pipih dan fusiform dan merupakan cacing ektoparasit dan memiliki haptor pada bagian posterior yang berfungsi untuk menempel pada inang, Ordo Dactylogyridea karena jangkar sebagai ciri khasnya (Kabata, 1985).

Pada kelas Cestoidea ciri-ciri parasit yang ditemukan berdasarkan hasil pengamatan morfologi termasuk dalam genus Unitubulotestis. Cacing ini memiliki ciri-ciri utama yaitu berupa warna tubuh kemerahan dan berbentuk pipih, serta memiliki segmen-segmen pada tubuhnya.

Tabel Hasil Identifikasi Ektoparasit Pada Ikan Mas Koki (Carassius auratus)

\begin{tabular}{|c|c|c|c|}
\hline No. & Ikan Ke- & Parasit Yang Ditemukan & Jumlah \\
\hline 1. & Ikan ke 1 & Dactylogyrus sp & 2 \\
\hline 2. & Ikan ke 2 & Tidak ditemukan & - \\
\hline 3. & Ikan ke 3 & Unitubulotestis sardae & 1 \\
\hline
\end{tabular}




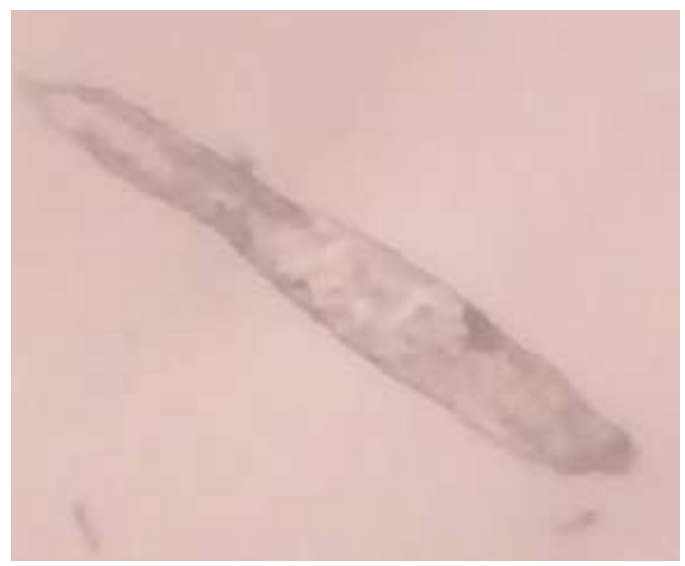

Dactylogyrus sp (40X)

Berdasarkan tabel dapat disimpulkan parasit yang menyerang ikan mas koki adalah Dactylogyrus sp dan Unitubulotestis sardae. Dactylogyrus sp merupakan ektoparasit yang mendiami insang ikan. Sedangkan Unitubulotesti sardae merupakan endoparasit yang menetap di saluran pencernaan pada vertebrata. Tetapi pada pengamatan ini Unitubulotestis sardae ditemukan di insang ikan dan lendir pada ikan. Kemungkinan hal ini terjadi karena air pada aquarium ikan tersebut sudah terkontaminasi oleh kotoran ikan yang terinfeksi oleh Unitubulotestis sardae sehingga parasit tersebut menempel pada insang dan lendir pada ikan.

\section{Dactylogyrus sp}

Dactylogyrus sp merupakan parasit yang menetap atau habitat hidupnya berada di insang ikan. Hidup di insang, tergolong Monogenea, punya kaki paku dan beracetabulum. Parasit yang matang melekat pada insang dan bertelur disana. Dactylogyrus sp merupakan cacing Trematoda dari sub-kelas Monogenea. Spesies tersebut berparasit pada hewan air berdarah dingin atau pada ikan, amfibi, reptil, kadang-kadang pada invertebrate air. Distribusinya luas, memiliki siklus hidup langsung dan merupakan parasit ekstemal pada insang, sirip, dan rongga mulut. Bisa juga ditemukan pada traktus urinaria. Cacing ini bersifat ovipar dan memiliki haptor yaitu organ untuk menempel yang dilengkapi dengan 2 pasang jangkar dan 14 kait di lateral (Yudhie, 2010). Intensitas reproduksi dan infeksi memuncak pada musim panas. Telur pada umumnya memliki operkulum dan filamen disalah satu ujungnya yang berfungsi untuk melekatkan telur pada hospes atau benda lain. Larva (oncomiridium) mempunyai silia dan eye spot lebih dari satu. Larva akan berenang dan menempel pada tubuh hospes kemudian menjadi dewasa di hospes (Kabata, 1985).

Dactylogyrus sp adalah parasit yang memiliki sepasang bintik mata, saluran usus yang

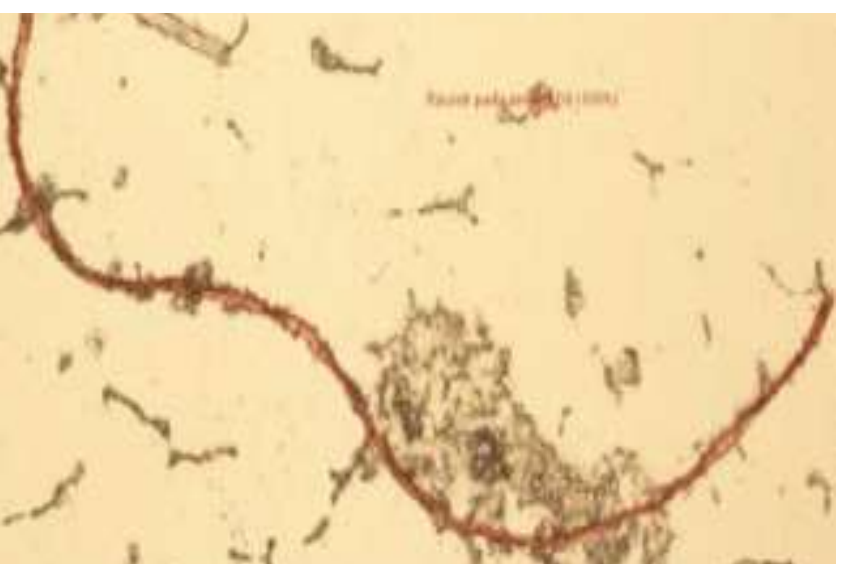

Unitubulotestis sardae (100X)

tidak jelas, sepasang jangkar yang tidak memiliki penghubung.. Menurut Retna, Adiputra, dan Wirdayanto (2014), klsifikasi Dactylogyrus sp adalah sebagai berikut:

$\begin{array}{ll}\text { Kingdom } & \text { : Animalia } \\ \text { Phylum : Platyhelminthes } \\ \text { Class } & : \text { Monogenea } \\ \text { Ordo } & : \text { Dactylogyridae } \\ \text { Family } & : \text { Dactylogyridae } \\ \text { Genus } & : \text { Dactylogyrus } \\ \text { Species } & : \text { Dactylogyrus sp }\end{array}$

\section{Unitubulotestis sardae}

Secara umum cacing dewasa dari kelas Cestoidea ini disebut cacing pita karena memiliki ciri-ciri sebagai berikut: morfologi umum pipih dorsoventral seperti pita. Tubuh cacing dari kelas cestoidea ini terdiri atas tiga bagian, yaitu kepala (scolex) yang dilengkapi dengan alat melekat atau sucker. Rostellum (semacam benjolan pada kepala), dan leher yang merupakan bagian bagian yang sempit antara kepala dan badan. Cacing ini memiliki panjang yang berbeda-beda, dari beberapa centimeter sampai mencapai 60 meter, dengan lebarnya beberapa milimeter.

Unitubulotestis sardae merupakan parasit jenis cacing yang termasuk dalam golongan atau kelas cestoidea. Berdasarkan pengamatan mikroskop, parasit ini ditemukan pada lendir dan organ insang dengan warna parasit kemerahan. Menurut Noble and Noble (1989), cacing ini termasuk dalam kelas cestoidea. Cestoidea merupakan cacing pita pipih. Segmen-segmen tubuhnya disebut proglotida. Kepala cacing pita merupakan suatu alat yang berfungsi untuk menempel pada inang disebut skoleks yang dilengkapi dengan kait-kait, organ pengisap. Jenis organ pengisap pada parasit ini disebut botria (Kristian, Sammy, Magdalena. 2014). Klasifikasi Unitubulotestis sardae menurut Jhon Chero (2015), sebagai berikut: 


$\begin{array}{ll}\text { Kingdom } & \text { : Animalia } \\ \text { Phylum } & \text { : Platyhelminthes } \\ \text { Class } & \text { : Trematoda } \\ \text { Subclass } & \text { : Digenea } \\ \text { Order } & \text { : Plagiorchiida } \\ \text { Family } & \text { : Didymozoidae } \\ \text { Genus } & \text { : Unitubulotestis } \\ \text { Spesies } & \text { : Unitubulotestis sardae }\end{array}$

\section{Kesimpulan}

Jenis ektoparasit yang menginfeksi ikan mas koki (Carassius auratus) yang dibeli dari penjual ikan hias Jalan Bintang Medan Sumatera Utara adalah Dactylogyrus sp dan Unitubulotestis sardae dengan ciri-ciri morfologi yang dimiliki oleh Dactylogyrus adalah memiliki bentuk tubuh pipih dan memiliki organ pelekatan pada inang, merupakan cacing ektoparasit dan memiliki haptor pada bagian posterior yang berfungsi untuk menempel pada inang, dan memiliki jangkar sebagai ciri khasnya. Sedangkan pada Unitubulotestis sardae memiliki ciri-ciri utama yaitu berupa warna tubuh kemerahan dan berbentuk pipih, serta memiliki segmen-segmen pada tubuhnya. Cacing ini merupakan endoparasit yang mendiami saluran pencernaan pada vertebrata. Tetapi pada pengamatan ini cacing tersebut terdapat di lendir dan insang ikan. Kemungkinan ha ini terjadi karena air dalam aquarium tersebut terkontaminasi oleh feses ikan yang terinfeksi oleh endoparasit ini.

\section{Daftar Pustaka}

Chero, Jhon. 2015. First Record Of Unitubulotestis pelamydis (Trematoda: Didymozoidae) And sphyriocephalus tergestinus (Cestoda: Sphyriocephalidae) In Eastern Pacific Bonito, Sarda Chiliensis (Perciformes: Scombridae) In Peru. APHIA. Vol. 9 No. 2: 313-323.
E. Efendi. 2013. Keragaman Karakter Morfologi antara Trichodina nobilis dan Trichodina reticulata pada Ikan Komet (Carrasius auratus). e-Jurnal Rekayasa dan Teknologi Budidaya Perairan. 1:121-123.

Handayani, Retna, Y. T. Adiputra, Wardiyanto. 2014. Identifikasi Dan Keragaman Parasit Pada Ikan Mas Koki (Carrasius auratus) Dan Ikan Mas (Cyprinus carpio) yang Berasal Dari Lampung Dan Luar Lampung. AQUASAINS. 150-156.

Kabata Z. 1985. Parasites and Diseases of Fish Cultured in the Tropic. London : Taylor dan Prancis.

Liviawaty E, Afrianto E. 1990. Mas Koki, Budidaya dan Pemasarannya. Cetakan I. Yogyakarta: Kanisius.

Nora Manurung, Usy dan Fatmawati Gaghenggang. 2016. Identifikasi dan prevalensi ektoparasit pada ikan Nila (Oreochromis niloticus) di kolam budidaya Kampung Hiung, Kecamatan Manganitu, Kabupaten Kepulauan Sangihe. Budidaya Perairan. Vol. 4 No. 2: $26-30$.

Purbomartono C, Isnaetin M dan Suwarsito. 2010. Ektoparasit Pada Benih Ikan Gurami (Osphronemus gouramy). Sains Akuatik. 10(1): 54-65.

Sauyai, Kristian, Sammy N.J. Longdong, Magdalena E.F. Kolopita. 2014. Identifikasi Parasit pada Ikan Kerapu Sunu, Plectropomus leopardus. Budidaya Perairan. Vol. 2 No. 3: 76 - 83.

Sumiati,Tuti dan Rani Aryati. 2010. Penyakit Parasitik Pada Ikan Air Tawar. Prosiding Forum Inovasi Teknologi Akuakultur. Hal. 963-967 